\title{
PENTINGNYA PENERAPAN PELAKSANAAN STANDAR PATIENT SAFETY TERKAIT MENINGKATKAN MUTU PELAYANAN KESEHATAN
}

\section{TATI OKTIANA TAMBA}

\author{
tatitamba26@gmail.com
}

\section{LATAR BELAKANG}

Keselamatan pasien dan mutu pelayanan kesehatan yang tinggi adalah tujuan akhir yang selalu diharapkan oleh rumah sakit, manajer, tim penyedia pelayanan kesehatan, pihak jaminan kesehatan, serta pasien, keluarga dan masyarakat. Namun demikian, prinsip "First, do no harm" tidak cukup kuat untuk mencegah berkembangnya masalah keselamatan pasien. Hal ini tercermin dari tingkat dan skala masalah keselamatan pasien sejak terbitnya publikasi "To Err is Human" pada tahun 2000. Keselamatan Pasien adalah suatu sistem dimana rumah sakit membuat asuhan terhadap pasien lebih aman, mencegah terjadinya cidera yang disebabkan oleh kesalahan akibat melaksanakan suatu tindakan atau tidak mengambil tindakan yang seharusnya diambil. Pada prinsipnya keselamatan pasien bukan berarti harus tidak ada resiko sama sekali agar semua tindakan medis dapat dilakukan. Salah satu masalah umum yang terjadi dalam pemberian pelayanan di bidang kesehatan adalah masalah yang berkaitan dengan keselamatan pasien.

Keselamatan pasien merupakan prioritas utama untuk dilaksanakan di rumah sakit dan hal tersebut terkait dengan isu mutu dan citra rumah sakit. Rumah sakit membutuhkan pengakuan dari masyarakat. Departemen Kesehatan R.I telah mencanangkan Gerakan Keselamatan Pasien Rumah Sakit sejak tahun 2005. Perhimpunan Rumah Sakit Indonesia (PERSI) menjadi pemprakarsa utama dengan membentuk Komite Keselamatan Pasien Rumah Sakit.

Keselamatan pasien menjadi isu terkini dalam pelayanan kesehatan rumah sakit sejak tahun 2000 yang didasarkan atas makin meningkatnya kejadian yang tidak diharapkan (KTD) atau adverse event. Adverse event merupakan suatu peristiwa yang dapat menyebabkan hal yang tak terduga 
atau tidak diinginkan sehingga membahayakan keselamatan pengguna alat kesehatan termasuk pasien atau orang lain. Klasifikasi adverse event adalah kejadian nyaris cedera (KNC), kejadian tidak cedera (KTC) dan sentinel (kematian atau cedera). Contoh dari KTD seperti medication error, flebitis, dekubitus, infeksi daerah operasi, dan pasien jatuh dengan cidera (Suhartono, 2013; Suryani et al., 2011).

Keselamatan Pasien (patient safety) merupakan isu global dan nasional bagi rumah sakit, komponen penting dari mutu layanan kesehatan, prinsip dasar dari pelayanan pasien dan komponen kritis dari manajemen mutu (WHO, 2004). Ada 5 (lima) isu penting yang terkait dengan keselamatan (safety) di rumah sakit yaitu : keselamatan pasien (patient safety), keselamatan pekerja atau petugas kesehatan, keselamatan bangunan dan peralatan di rumah sakit yang bisa berdampak terhadap keselamatan pasien dan petugas, keselamatan lingkungan (green productivity) yang berdampak terhadap pencemaran lingkungan dan keselamatan "bisnis" rumah sakit yang terkait kelangsungan hidup rumah sakit.Namun harus diakui kegiatan institusi rumah sakit dapat berjalan apabila ada pasien. Karena itu keselamatan pasien merupakan prioritas utama untuk dilaksanakan dan hal tersebut terkait dengan isu mutu dan citra perumah sakitan (Depkes RI, 2008).

The Institute of Medicine (IOM mendefinisikan keselamatan sebaga freedom from accidental injury.Keselamatan dinyatakan sebagai ranah pertama dari mutudan definisi dari keselamatan ini merupakan pernyataan dari perspektif pasien (Kohn, dkk, 2000 dalam Sutanto, 2014). Pengertian lain menurut Hughes (2008) dalam Sutanto (2014), menyatakan bahwa keselamatan pasien merupakan pencegahan cedera terhadap pasien. Pencegahan cedera didefinisikan sebagaibebas dari bahaya yang terjadi dengan tidak sengaja atau dapat dicegah sebagai hasil perawatan medis. Sedangkan praktek keselamatan pasien diartikan sebagai menurunkan risiko kejadian yang tidak diinginkan yang berhubungan dengan paparan terhadap lingkup diagnosis atau kondisi perawatan medis.Tujuan dari penelitian ini adalah dengan dibuatnya kebijakan keselamatan pasien dirumah sakit akan membuat Terciptanya suatu lingkungan kerja yang aman, sehat bagi pasien/keluarga pasien, masyarakat dan lingkungan sekitar rumah sakit, sehingga proses pelayanan rumah sakit berjalan dengan lancar dan baik tidak menimbulkan masalah keselamatan dan keamanan pasien.Serta bertujuan untuk mengetahui kebijakan peningkatan mutu dan keselamatan pasien. 


\section{METODE}

Metode penelitian yang digunakan dalam kajian ini adalah kajian yang dibuat dengan menganalisis, mengekplorasi atau menggabungkan kajian kumulatif dan kualitatif dari berbagai sumber ilmiah yang,berlandaskan teori dari buku atau jurnal atau e-book ataupun sumber informasi lainnya yang memuat informasi dengan pembahasan kebijakan keselamatan pasien,kemudian dikembangkan berdasarkan aturan dan konsep yang sesuai. Dengan metode ini informasi pembahasan mengenai keselamatan pasien bagi seorang perawat dapat mengupayakan untuk selalu mentaati peraturan dan kebijakan keselamatan pasien dengan baik agar pasien yang dirawat dapat terhindar dari kecelakaan sehingga meningkatkan mutu pelayanan kesehatan.

\section{HASIL}

Agar peningkatan mutu dan keselamatan pasien dapat berjalan baik, direktur rumah sakit, para kepala bidang, serta kepala unit dan departemen di rumah sakit :

o Wajib mendorong pelaksanaan program peningkatan mutu dan keselamatan pasien

o Berupa mendorong pelaksanaan budaya mutu dan keselamatan (quality and safety culture)

o Secara proaktif melakukan identifikasi dan menurunkan variasi

o Menggunakan data agar fokus kepada prioritas isu

o Berupaya menunjukkan perbaikan yang berkelanjutan (Harahap, 2018)

Perawat memahami keselamatan pasien adalah yang paling utama dilakukan dalam tindakan asuhan keperawatan dan mengambil keputusan dengan aman dan tepat. Penerapan kebijakan keselamatan pasien dapat dimulai dengan kegiatan tahap perencanaan, pengorganisasian, pelaksanaan, dan pengendalian yang bertujuan untuk membudayakan keselamatan dirumah sakit, sehingga tidak terjadi kejadian yang tidak diharapkan. 
Berdasarkan hasil perbandingan dari berbagai sumber ilmiah diperoleh hasil yaitu masih adanya perawat yang belum menerapkan upaya atau pelaksanaan keselamatan pasien di rumah sakit. Hal ini dipengaruhi karena perawat tidak berlandaskan pengetahuan yang penuh atau tingkah pengetahuan yang dimiliki perawa $\mathrm{t}$ masih rendah.

Meskipun demikian telah di sebutkan dari salah satu jurnal tersebut bahwasanya jika penerapan keselamatan pasien dilakukan dengan baik maka pelayanan yang mengutamakan keselamatan dan kualitas yang optimal akan memberikan dampak yang luas terutama bagi masyarakat yang mendapatkan pelayanan kesehatan dengan aman, berkualitas dan memenuhi harapan klien. Pelayanana yang baik dan berkualitas dapat meningkatkan kepercayaan public terhadap Rumah Sakit tersebut.

\section{PEMBAHASAN}

Keamanan dan keselamatan merupakan kebutuhan dasar manusia, yang merupakan kebutuhan prioritas kedua setelah kebutuhan fisiologis pada Hirarki kebutuhan Maslow. Keamanan tidak hanya pencegahan kecelakaan dan injury tetapi juga mengijinkan seseorang untuk merasakan bebas dalam beraktivitas tanpa bahaya. Keamanan mengurangi stress, meningkatkan status kesehatan umum. Keamanan memungkinkan seseorang untuk memenuhi kebutuhan dasar mereka seperti dicintai dan mencintai dan harga diri dan memungkinkan seseorang mencapai kebutuhannya. Dampak positif dalam kehidupannya adalah menghasilkan status kesehatan mental yang lebih baik dan fungsi individu lebih efektif (Craven, 2001 yang dikutip oleh Susanto, 2006). Keamanan seringkali didefinisikan sebagai keadaan bebas dari cedera fisik dan psikologis, adalah salah satu kebutuhan dasar manusia yang harus dipenuhi. Lingkungan pelayanan kesehatan dan komunitas yang aman merupakan hal yang penting untuk kelangsungan hidup klien.

Keselamatan pasien (patient safety) rumah sakit adalah suatu sistem dimana rumah sakit membuat asuhan pasien lebih aman. Sistem tersebut meliputi asesmen risiko, identifikasi dan pengelolaan hal yang berhubungan dengan risiko pasien, pelaporan dan analisis insiden, kemampuan belajar dari insiden dan tindak lanjutnya serta implementasi solusi untuk 
meminimalkan timbulnya risiko. Sistem tersebut diharapkan dapat mencegah terjadinya cedera yan disebabkan oleh kesalahan akibat melaksanakan suatu tindakan atau tidak melakukan tindakan yang seharusnya dilakukan. (Panduan Nasional Keselamatan Pasien Rumah sakit, Depkes R.I. 2006).

WHO Health Assembly ke 55 Mei 2002 menetapkan resolusi yang mendorong (urge) negara untuk memberikan perhatian kepada problem Patient Safety meningkatkan keselamatan dan sistem monitoring. Pada bulan Oktober 2004, WHO dan berbagai lembaga mendirikan "World Alliance for Patient Safety" dengan tujuan mengangkat isu Patient Safety Goal "First do no harm" dan menurunkan morbiditas, cedera dan kematian yang diderita pasien. (WHO: World Alliance for Patient Safety, Forward Programme, 2004). Tujuan dilakukannya kegiatan Patient Safety di rumah sakit adalah untuk menciptakan budaya keselamatan pasien di rumah sakit, meningkatkan akuntabilitas rumah sakit, menurunkan KTD di rumah sakit, terlaksananya program-program pencegahan sehingga tidak terjadi pengulangan kejadian tidak diharapkan. Mengingat masalah keselamatan pasien merupakan masalah yang penting dalam sebuah rumah sakit, maka diperlukan standar keselamatan pasien rumah sakit yang dapat digunakan sebagai acuan bagi rumah sakit di Indonesia.

Standar keselamatan pasien rumah sakit yang saat ini digunakan mengacu pada "Hospital Patient Safety Standards" yang dikeluarkan oleh Join Commision on Accreditation of Health Organization di Illinois pada tahun 2002 yang kemudian disesuaikan dengan situasi dan kondisi di Indonesia. Penilaian keselamatan yang dipakai Indonesia saat ini dilakukan dengan menggunakan instrumen Akreditasi Rumah Sakit yang dikeluarkan oleh KARS. Departemen Kesehatan RI telah menerbitkan Panduan Nasional Keselamatan Pasien Rumah Sakit (Patient Safety) edisi kedua pada tahun 2008 yang terdiri dari dari 7 standar, yakni: 1.) Hak pasien 2.) Mendididik pasien dan keluarga 3.) Keselamatan pasien dan kesinambungan pelayanan 4.) Penggunaan metoda metoda peningkatan kinerja untuk melakukan evaluasi dan program peningkatan keselamatan pasien 5.) Peran kepemimpinan dalam meningkatkan keselamatan pasien 6.) Mendidik staf tentang keselamatan pasien 7.) Komunikasi merupakan kunci bagi staf untuk mencapai keselamatan pasien Tujuh Langkah.

Salah satu tugas perawat adalah mengkaji bahaya yang mengancam keamanan klien dan lingkungan, dan selanjutnya melakukan intervensi yang diperlukan. Dengan melakukan hal ini, 
maka perawat adalah orang yang berperan aktif dalam usaha pencegahan penyakit, pemeliharaan kesehatan, dan peningkatan kesehatan. Lingkungan klien mencakup semua faktor fisik dan psikososial yang mempengaruhi atau berakibat terhadap kehidupan dan kelangsungan hidup klien. Definisi yang luas tentang lingkungan ini menggabungkan seluruh tempat terjadinya interaksi antara perawat dan klien, contohnya rumah, pusat komunitas, klinik, rumah sakit, dan tempat perawatan jangka panjang. Keamanan yang ada dalam lingkungan ini akan mengurangi insiden terjadinya penyakit dan cedera, memperpendek lama tindakan dan/atau hospitalisasi, meningkatkan atau mempertahankan status fungsi klien, dan meningkatkan kesejahteraan klien.

Lingkungan yang aman juga akan memberikan perlindungan kepada stafnya, dan memungkinkan mereka untuk berfungsi pada tingkat yang optimal (Potter and Perry, 1995). Lingkungan yang aman adalah salah satu kebutuhan dasar yang terpenuhi, bahaya fisik akan berkurang, penyebaran mikroorganisme pathogen akan berkurang, sanitasi dapat dipertahankan, dan polusi dapat dikontrol. Kebutuhan dasar manusia, terutama kebutuhan fisiologis yang terdiri dari kebutuhan terhadap oksigen, kelembaban yang optimum, nutrisi dan suhu yang optimum, akan mempengaruhi keamanan seseorang. Pemenuhan kebutuhan dasar fisiologis manusia diperlukan untuk mencapai kebutuhan keamanan dan keselamatan. Pengetahuan tentang pengontrolan injury sangat perlu dan dibutuhkan dalam beberapa tahun terakhir ini yang ditujukan pada komponen hal-hal yang membahayakan kemanan yang berkontribusi pada injury baik non fatal maupun fatal. Istilah kecelakaan tidak begitu luas akan digunakan dalam diskusi pencegahan injury, karena kecelakaan diimpilikasikan pada kejadian yang terjadi karena kehendak Tuhan atau keberuntungan yang buruk, yang tidak dapat diduga, dan yang tidak dapat dicegah. Seperti halnya,kecelakaan,maka injury memiliki sesuatu cara yang harus dicegah.

\section{Rumah Sakit}

Rumah sakit merupakan salah satu tempat/isntitusi pelayanan kesehatan bagi masyarakat yang datang dengan keadaan sehat maupun sakit dengan karakteristik masing-masing klien dan dilayani oleh berbagai tim pelayan kesehatan dengan berbagai macam perkembangan ilmu pengetahuan di bidang kesehatan, kemajuan teknologi, maupun kehidupan sosial ekonomi masyarakat. Rumah sakit merupakan sebuah institusi pelayanan kesehatan bagi masyarakat dengan karakteristik tersendiri yang dipengaruhi oleh berbagai macam perkembangan ilmu 
pengetahuan di bidang kesehatan, kemajuan teknologi, maupun kehidupan sosial ekonomi kemarakatan.

\section{Keselamatan Pasien}

Keselamatan Pasien di RS adalah sistem pelayanan dalam suatu RS yang memberikan asuhan pasien menjadi lebih aman. Keselamatan pasien merupakan suatu sistem yang sangat dibutuhkan mengingat saat ini banyak pasien yang dalam penanganannya sangat memprihatinkan, dengan adanya sistem ini diharapkan dapat meminimalisir kesalahan dalam penanganan pasien. Keselamatan pasien merupakan sebuah upaya yang dilakukan oleh perawat untuk menghindari, mencegah serta memperbaiki kesalahan yang merugikan pasien dalam proses pelayanan.

Keselamatan Pasien menjadi isu terkini dalam pelayanan kesehatan terutama dalam pelayanan kesehatan rumah sakit sejak tahun 2000 yang didasarkan atas semakin meningkatnya kejadian yang tidak diinginkan. Program keselamatan pasien telah menjadi isu global dan menjadi bagian dari program kesehatan dunia sejak tahun 2004. Dalam program ini juga dinyatakan bahwa keselamatan pasien merupakan prinsip fundamental pelayanan pasien dan merupakan sebuah komponen kritis dalam manajemen mutu (WHO, 29004).

\section{Pelaksanaan Keselamatan Pasien}

Pelaksanaan Pasien Safety yang masih rendah tidak terlepas dari pemahaman responden yang masih kurang. Kurangnya pemahaman responden/klien sangat mempengaruhi dalam melaksanakan pelayanan pasien safety. Pelaksanaan Keselamatan Pasien yang diamati dari enam sasaran keselamatan pasien, yaitu indentitas pasien, peningkatan komunikasi efektif,peningkatan pemakaian obat dengan dengan kewaspadaan tinggi, kepastian tepat lokasi, tepat prosedur, tepat pasien operasi, pencegahan resiko infeksi, dan pengurangan resiko jatuh. Pada penerapan sistem keselamatan pasien di RS ada aspek-aspek yang harus dibangun atau ditingkatkan diantaranya kemampuan, sikap petugas pelaksana pelayanan kesehatan maupun sistem atau organisasi. Pelayanan Keperawatan memiliki peran yang sangat besar dalam pelayanan di RS, bukan hanya dari jurnal tenaga keperawatan yang banyak akan tetapi pelayanan yang terus-menerus dan berkesinambungan kinerja perawat dan Penerapan keselamatan pasien berhubungan erat dengan KTD terhadap pasien. Salah satu upaya yang diakukan perawat dalam pencegahan KTD adalah 
peningkatan kemampuan perawat dalam melakukan pencegahan dini, deteksi resiko dan koreksi terhadap abnormalitas (Deokes RI. 2006).

\section{PENUTUP}

Untuk mewujudkan patient safety dibutuhkan upaya dan kerjasama berbagai pihak. Patient safety merupakan upaya dari seluruh komponen sarana pelayanan kesehatan, dan perawat memegang peran kunci untuk mencapainya.Meningkatkan kemampuan perawat dalam mengkategorikan status kesehatan klien dalam menghitung secara benar dan akurat menggunakan Skala jatuh Morse dalam bentuk pelatihan atau kursus dalam Program Patient Safety di Rumah Sakit dan Pendokumentasian yang baik haruslah lebih ditingkatkan, untuk itu perawat secara berkala dan berkesinambungan sehingga asuhan keperawatan dapat diberikan secara komprehensif.

Kebijakan K3RS adalah Segala kegiatan untuk menjamin dan melindungi keselamatan dan kesehatan bagi sumber daya manusia di rumah sakit, pasien, pendamping pasien, pengunjung, maupun lingkungan rumah sakit melalui upaya pencegahan kecelakaan kerja dan penyakit akibat kerja di rumah sakit.Jika kebijakan keselamatan pasien di pelayanan kesehatan dirancang maka kegiatan untuk melindungi keselamatan pasien dapat terlaksana. Dengan membuat suatu kegiatan kepada seluruh tim kesehatan untuk membudidayakan kebijakan yang dibuat dengan sebaikbaiknya agar rumah sakit dapat menajdi fasilitas pelayanan kesehatan yang aman .

Berdasarkan hasil kajian dengan metode analisis, eksplorasi dan kajian bebas ini dapat disimpulkan bahwa keselamatan pasien itu yang utama dalam asuhan pelayanan kesehatan terhadap pasien. Penerapan yang dilakukan di rumah sakit dengan pelayanan yang optimal, berkualitas dapat meningkatkan atau mengharumkan nama baik rumah sakit karena hasil kinerja yang dilakukan tim pelayanan kesehatan di RS. 


\section{DAFTAR PUSTAKA}

Adi utarini hanevi \& djasri. (Desember 2012). Keselamatan pasien dan mutu pelayanan kesehatan : Menuju kemana?. Jurnal manajemen pelayanan kesehatan,Vol.15,No.4

Amelia Kurniati,Yanny Trisyani,Siwi Teresia. (2018). Keperawatan Gawat Darurat dan Bencana Sheehy.Editor edisi Indonesia : ELSEVIER ( Suthichana Tharpamalan)

Cecep Triwibowo, Sulhah Yuliawati,Nur Amri Husna. (Juli 2016). HANDOVER SEBAGAI UPAYA PENINGKATAN KESELAMATAN PASIEN (PATIENT SAFETY) DI RUMAH SAKIT. Jurnal Keperawatan Soedirman (The Soedirman Journal of Nursing), Volume 11, No.2

Dr.Febri,Prof.Dr.Stefanus Supriyanto. (Maret 2019). Manajemen Rumah Sakit. Zifatama Jawara

Muhammad Yusuf. (2017). Penerapan patient safety di ruang rawat inap rumah sakit umum daerah Dr.zainoel Abidin. Jurnal ilmu keperawatan,5:1

Nanda Hani Juniarti,Ahmad Ahmad mudayana.2018 .Penerapan standar keselamatan pasien di rumah sakit umum daerah provinsi provinsi Nusa Tenggara Barat .Fakultas kesehatan masyarakat Universitas Ahmad Dahlan Yogyakarta : Jurnal Kesehatan Poltekkes Ternate,11(2)

Setya Enti Rikomah . (Februari 2016). Farmasi Klinik. Cetakan 1,Yogyakarta : Deepublish

Simamora, R. H., \& Nurmaini, C. T. S. (2019). Knowledge of Nurses about Prevention of Patient Fall Risk in Inpatient Room of Private Hospital in Medan. Indian Journal of Public Health Research \& Development, 10(10), 759-763.

Sumarni. 2017 .Analisis implementasi patient safety terkait peningkatan mutu pelayanan kesehatan di Rumah Sakit. JNKI ,vol.5 ,No.2

Tria Harsiwi Nurul Insani, Sri Sundari. (Maret 2018). Analisis Pelaksanaan Keselamatan Pasien oleh Perawat. Journal of Health Studies, Vol. 2, No. 1

Yennike Tri Herawati . (Maret 2015 ) .Budaya keselamatan pasien di ruang rawat inap rumah sakit X Kabupaten Jember. Jurnal IKESMA,Vol.11, No.1 
